\title{
Decreased ATM Function Causes Delayed DNA Repair and Apoptosis in Common Variable Immunodeficiency Disorders
}

\author{
Chantal E. Hargreaves ${ }^{1} \cdot$ Silvia Salatino $^{2} \cdot$ Sarah C. Sasson $^{1} \cdot$ James E. G. Charlesworth ${ }^{3}$. Elizabeth Bateman ${ }^{4}$. \\ Arzoo M. Patel ${ }^{1}$. Consuelo Anzilotti ${ }^{5}$. John Broxholme ${ }^{2}$. Julian C. Knight ${ }^{2} \cdot$ Smita Y. Patel $^{1,5}$
}

Received: 16 December 2020 / Accepted: 20 April 2021 / Published online: 19 May 2021

(c) The Author(s) 2021

\begin{abstract}
Purpose Common variable immunodeficiency disorders (CVID) is characterized by low/absent serum immunoglobulins and susceptibility to bacterial infection. Patients can develop an infections-only phenotype or a complex disease course with inflammatory, autoimmune, and/or malignant complications. We hypothesized that deficient DNA repair mechanisms may be responsible for the antibody deficiency and susceptibility to inflammation and cancer in some patients.

Methods Germline variants were identified following targeted sequencing of $n=252$ genes related to DNA repair in $n=38$ patients. NanoString nCounter PlexSet assay measured gene expression in $n=20$ CVID patients and $n=7$ controls. DNA damage and apoptosis were assessed by flow cytometry in $n=34$ CVID patients and $n=11$ controls.

Results Targeted sequencing supported enrichment of rare genetic variants in genes related to DNA repair pathways with novel and rare likely pathogenic variants identified and an altered gene expression signature that distinguished patients from controls and complex patients from those with an infections-only phenotype. Consistent with this, flow cytometric analyses of lymphocytes following DNA damage revealed a subset of CVID patients whose immune cells have downregulated ATM, impairing the recruitment of other repair factors, delaying repair and promoting apoptosis.

Conclusion These data suggest that germline genetics and altered gene expression predispose a subset of CVID patients to increased sensitivity to DNA damage and reduced DNA repair capacity.
\end{abstract}

Keywords Apoptosis · common variable immunodeficiency disorders · CVID · DNA damage and repair · primary antibody deficiency

Chantal E. Hargreaves

chantal.hargreaves@ndm.ox.ac.uk

1 Nuffield Department of Medicine and Oxford NIHR Biomedical Research Centre, University of Oxford, Oxford OX3 9DU, UK

2 Wellcome Centre for Human Genetics, University of Oxford, Oxford OX3 7BN, UK

3 Oxford University Clinical Academic Graduate School, Medical Sciences Office, John Radcliffe Hospital, University of Oxford, OX3 9DU Oxford, UK

4 Department of Immunology, Churchill Hospital, Oxford University Hospitals NHS Trust, Oxford OX3 7LE, UK

5 Clinical Immunology Department, Oxford University Hospitals Trust, Oxford OX3 9DU, UK

\section{Introduction}

Common variable immunodeficiency disorders (CVID) is the most clinically prevalent cause of primary antibody failure in adults and children, with an incidence of 1:25,000 [1]. Characterized by recurrent infections; low serum levels of IgG, IgM, and/or IgA; and poor-specific antibody responses [2], CVID has a heterogeneous clinical course. The majority of patients have an infections-only phenotype. A subset develops a complex phenotype that can involve autoimmune cytopenia, polyclonal lymphoproliferation, enteropathy, and malignancy [3]. A complex phenotype is associated with a higher mortality rate than other patients and the general population [4].

CVID is a diagnosis of exclusion, with a genetic contribution known for only $10-30 \%$ of patients, depending on the cohort [5]. A recent study identified NFKB1 as the predominant (4\%) monogenic cause of a CVID-like phenotype [6]. 
A genome-wide association study (GWAS) of 363 CVID patients found multiple susceptibility loci, concluding that sporadic CVID is likely a polygenic disease [7]. Our previous whole genome sequencing (WGS) study of 31 sporadic CVID patients confirmed this and identified an enrichment of rare variants in genes related to DNA repair pathways. A majority (54\%) of patients had at least one variant in a gene involved in a DNA repair pathway [8]. These data suggest that the accumulation of variants in multiple pathways may contribute to disease pathogenesis.

Double-stranded DNA breaks (DSBs) are potentially dangerous lesions yet are key to an effective immune response through somatic recombination and hypermutation of lymphocyte receptors $[9,10]$ using multiple DNA repair pathways $[11,12]$. DSBs are recognized by ATM, which is activated through its autophosphorylation at serine 1981 following its recruitment by the damage-sensing MRN complex (MRE11A-Rad50-NBS1) [13]. The histone H2A variant, $\mathrm{H} 2 \mathrm{AX}$, is phosphorylated at serine 139 following DNA damage, by ATM, ATR, and DNA-PKcs to become $\gamma \mathrm{H} 2 \mathrm{AX}$ [14]. Foci of $\gamma \mathrm{H} 2 \mathrm{AX}$ spread at the sites of DSBs and initiate the recruitment and maintenance of other factors for their repair [15].

$\mathrm{V}$ (D)J recombination involves programmed DSBs repaired by non-homologous end-joining and homologous recombination repair. The mismatch and base excision repair pathways generate and repair the base mismatches and DNA breaks essential for somatic hypermutation and class-switch recombination $[16,17]$. The essential role of these pathways in the immune system is best demonstrated by primary immune deficiencies caused by monogenic defects in DNA repair genes [18]. There are multiple lines of evidence for the role of defective DNA repair in CVID given the low serum immunoglobulins, defective isotype switching, alterations in somatic hypermutation $[19,20]$ and increased risk of malignancy compared to the general population [3, 21].

We hypothesized that multiple variants in genes related to DNA repair pathways predispose to CVID and its associated complications. Here, we sought to validate our WGS data through targeted resequencing of genes related to DNA repair in an extended CVID cohort and functional testing of the DNA repair response in vitro by measuring repair markers and damage-induced apoptosis.

\section{Methods}

\section{Characteristics of Patient and Control Cohorts}

Patients with CVID $(n=38)$ or primary antibody deficiency (PAD; $n=2$ ) were recruited through the Clinical Immunology Department, John Radcliffe Hospital, Oxford, UK. The median age of patients at the time of study sample collection was 50.1 years (range 20.8-80), and 50\% were female. The median age was 49.3 years for infections-only patients and 51 years for complex patients. A monogenic cause was excluded by WGS in 19 CVID patients. PAD patients did not meet CVID diagnostic criteria, as onset was $<4$ years old, and were included in case dysregulated DNA repair was a cause of their antibody failure. Patients met the European Society for Immunodeficiencies diagnostic criteria at the time of enrolment [2]. All participants gave informed written consent, and studies were performed according to the Declaration of Helsinki with South Central Research Ethics Committee approval (12/SC/0044). Control blood samples $(n=13)$ were obtained from self-reporting healthy staff members at the University of Oxford through the Oxford Gastrointestinal Illness Biobank (16/YH/0247). The median age of controls was 35 years (range 24-48), and 64\% were female. Patients' clinical characteristics are described in Table S1. Due to limitations on primary cellular material, it was not possible to perform all experiments on all participants (Table S2).

\section{HaloPlex HS Library Preparation, Sequencing, and Analysis}

A custom HaloPlex HS targeted enrichment assay (Agilent) of 252 genes related to DNA repair was designed using Agilent's Sure Design software. Custom probes were designed targeting the exons and $5^{\prime}$ and $3^{\prime}$ untranslated regions with an extra 50 base pairs (bp) using the hg19 genome build. Probes were also targeted to 23 genomic regions to improve probe coverage (Table S3).

HaloPlex HS libraries were prepared for $n=36$ CVID and $n=2$ PAD patients. Genomic DNA was extracted from peripheral blood mononuclear cells (PBMCs) using FlexiGene DNA or DNeasy Blood and Tissue kits (Qiagen). A 50 ng of DNA was enzymatically digested and hybridized for $16 \mathrm{~h}$ to custom probes. Circularized fragments were ligated, captured, and amplified by PCR. Libraries were purified with AMPure beads (Beckman Coulter) and quantified with a Bioanalyzer 2100 and High Sensitivity DNA chips (Agilent). Equimolar library pools were prepared for 150 bp paired-end sequencing with an Illumina HiSeq 4000 (Illumina) at Oxford Genomics Centre, Wellcome Centre for Human Genetics, University of Oxford.

\section{Bioinformatic Analysis Pipeline}

Quality control for the sequenced reads was performed with an in-house Python-based pipeline. Prior to alignment, Agilent SurecallTrimmer (version 4.0.1) was used to trim adapter sequences and low-quality bases and mask enzyme footprints. Reads were mapped to the hs37d5 version of the human reference build 37 using BWA mem (version 0.7.15) [22], and 
only reads in proper pairs and with insert sizes ranging from 30 to 625 were retained using bamtools (https://github.com/ pezmaster31/bamtools). UMIs were added using AddUMIsToBam (https://github.com/mbusby/AddUMIsToBam). Picard (version 2.9.2) http://broadinstitute.github.io/picard/) was used to fix mate CIGAR strings, merge files from multiple sequencing lanes, and deduplicate BAM files.

Platypus (version 0.8.1, default parameters) [23] identified SNVs and short $(<50 \mathrm{bp})$ indels within each sample. Variants were annotated with an in-house pipeline written in Python using the Variant Effect Predictor framework (VEP, version 77) [24] as well as 1000 Genomes Project [25], UK10K [26], Exome Variant Server (ESP6500, http://evs.gs. washington.edu/EVS/), and Exome Aggregation Consortium (ExAC, http://exac.broadinstitute.org/) databases. Known associations with diseases were screened using HGMD (http://www.hgmd.cf.ac.uk) and ClinVar [27].

Variants were filtered using BrowseVCF [28] based on the criteria outlined in Table S4. Oncoplots were generated using the Maftools R Bioconductor package [29]. Variants were prioritized based on being novel and/or predicted pathogenic using American College of Medical Genetics and Genomics (ACMG) guidelines [30] (Table 1). Variants present in public databases with an unknown significance or predicted benign/likely benign are shown in Table S5.

\section{PBMC Isolation}

PBMCs were isolated with Lymphoprep (Stem Cell Technologies), washed, and stored in fetal bovine serum (FBS; Sigma) with $10 \%$ DMSO (Sigma) in liquid nitrogen. Defrosted cells were washed twice and re-suspended in RPMI-1640 (Lonza) supplemented with 10\% FBS, sodium pyruvate, non-essential amino acids, $\beta$-mercaptoethanol, penicillin, and streptomycin (Sigma). Viability and cell counts were assessed using a hemocytometer and trypan blue.

\section{Targeted mRNA Gene Expression Profiling}

PBMCs $\left(0.5 \times 10^{6}\right)$ from $n=7$ controls and $n=20$ patients were pelleted at $1600 \mathrm{rpm}$ for $8 \mathrm{~min}$, lysed with RLT buffer (Qiagen), diluted 1:3 with deionized water, and stored at $-80^{\circ} \mathrm{C}$ until analysis. Cell lysates (80,000 cells) were hybridized with NanoString nCounter DNA Damage Repair PlexSet-96 probes and $0.2 \mathrm{mg} / \mathrm{mL}$ Proteinase K (Beckman Coulter) for $17.5 \mathrm{~h}$ at $67{ }^{\circ} \mathrm{C}$. Libraries were applied to an nCounter SPRINT Cartridge and nCounter SPRINT Profiler (NanoString). Raw data were analyzed using nProfiler software (NanoString), DESeq2 [31] and RStudio (version 1.2.5019). Differentially expressed genes were classified as having a $\log ^{2}$ FoldChange $>0.5$ and a false discovery rate $($ FDR $)<0.05$.

\section{Flow Cytometry}

PBMCs from $n=11$ controls, $n=32$ CVID and $n=2$ PAD patients were either untreated or exposed to $5 \mathrm{~Gy}$ of $\gamma$-irradiation and cultured for 1 or $24 \mathrm{~h}$. Cells were stained with Fixable Live/Dead eF780 (ThermoFisher), CD3-BV785 (clone: SK7), CD4-BV510 (SK3), CD8-PE-Cy7 (HIT8a) and CD19-BV605 (HIB19) in PBS, 5\% bovine serum albumin, and $0.09 \%$ sodium azide for $10 \mathrm{~min}$ at room temperature. Cells were washed and fixed with eBioscience FoxP $3 /$ Transcription Factor Staining Buffer Set fixative (eBioscience) for $1 \mathrm{~h}$ at $4{ }^{\circ} \mathrm{C}$. Cells were permeabilized in the presence of $\gamma \mathrm{H} 2 \mathrm{AX}^{\mathrm{Ser} 139}$-FITC (2F3), ATM ${ }^{\text {Ser1981 }}$-PE (10H11. E12), 53BP1-AF700 (cat. no. NB100-904; Novus Biologics) and cleaved PARP Asp214-PE-CF594 (F21-852, BD Biosciences) for $1 \mathrm{~h}$ at $4{ }^{\circ} \mathrm{C}$. Antibodies were obtained from Biolegend unless otherwise stated. Samples were analyzed using an LSR Fortessa (BD Biosciences) and FlowJo version 9 software (Tree Star).

\section{Statistical Analyses}

Statistical analyses were performed using GraphPad Prism version 8. Non-parametric distribution of data was determined using D'Agostino and Pearson test. Statistical significance is defined as $* p<0.05, * * p<0.01, * * * p<0.001$, and $* * * * p<0.0001$.

\section{Results}

\section{Targeted Resequencing of DNA Repair-Related Genes in CVID}

Our previously published WGS analysis provided evidence for the polygenic nature of sporadic CVID and a disease etiology based on the contribution of multiple interacting genes and pathways [8]. Of particular interest was the enrichment of likely pathogenic rare variants in genes related to DNA repair pathways. We sought to validate these data through targeted resequencing of a custom selection of 252 genes related to DNA repair pathways in a cohort of 36 sporadic CVID and 2 PAD patients.

Targeted DNA resequencing of $n=38$ patients identified a total of 84,922 variants. Filtering excluded variants with a $>1 \%$ frequency in 1000 genomes [25], ExAC [32], ESP6500, and UK10K [26] public databases (Table S4), to allow identification of causative and disease-modifying variants. Exclusion of synonymous, non-coding, and low complexity region variants left 136 heterozygous variants, of which 32 were novel and 24 were below $0.1 \%$ frequency. The majority of the polymorphisms were missense, SNVs were more prevalent than insertions or deletions, and $\mathrm{C}>\mathrm{T}$ 


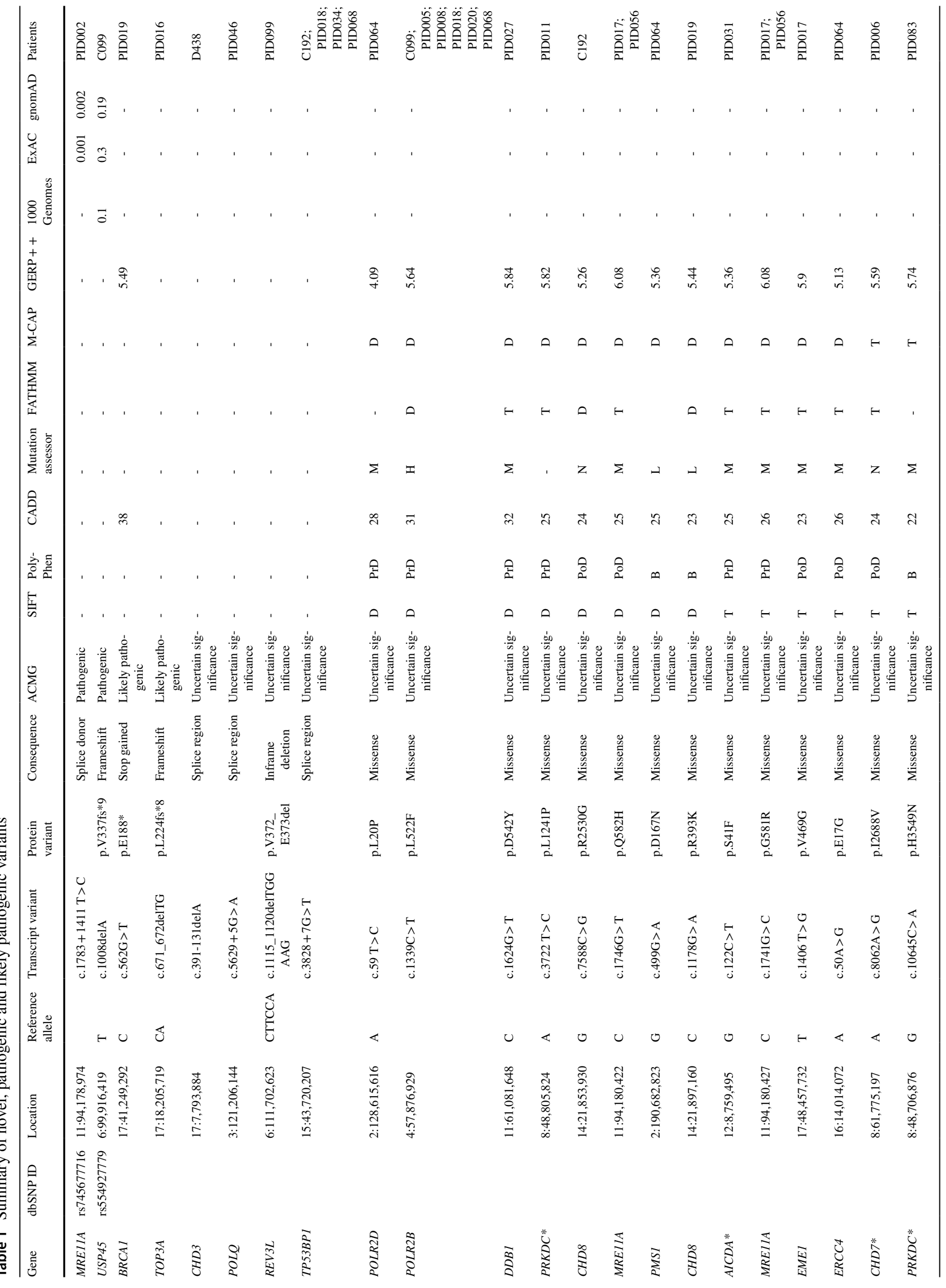




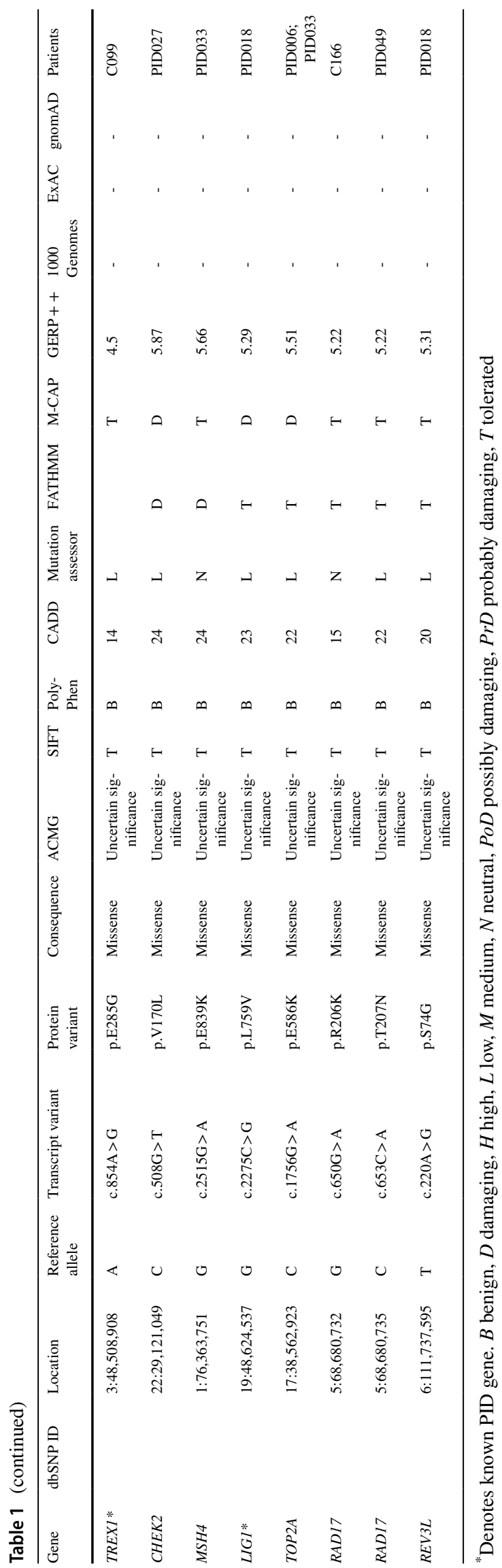

transitions were the most common SNV type. There was a median of 4.5 variants per individual (range 1-12), a median of 4 (range 2-12) among complex patients and a median of 5 (range 1-9) among infections-only patients. The most variable genes were TP53BPl (18\%), POLR2B (16\%), and GEN1 (13\%) (Fig. 1a). Each patient's combination of variable genes and variant types is summarized by oncoplot in Fig. $1 b$.

We identified predicted pathogenic variants in MRE11A (splice donor c.1783+1411 T >C) and USP45 (p.V337fs*9) and likely pathogenic variants in BRCAl (p.E188*) and TOP3A (p.L224fs*8). Novel genes classified as of uncertain significance based on their absence from public databases are detailed in Table 1.

For genes involved in $\mathrm{V}(\mathrm{D}) \mathrm{J}$ recombination, we found novel missense variants in AICDA (p.S41F) and $P R K D C$ (p.L1241P) (Table 1) and rare missense variants in DCLRE1C (p.L214M), DNTT (p.R460Q), PRKDC (p.R2595H), POLL (p.G376S and p.303S), and POLM (p.G220A) (Table S5). We identified novel and rare variants in pathways including homology-directed recombination (MRE11A p.Q582H, p.G581R, and c.1867 + $2 \mathrm{~T}>\mathrm{C}$ ), mismatch repair (MSH3 p.Glu437fs*10), nucleotide excision repair (ERCC4 p.E17G), and chromatin organization (CHD7 p.S842Y and CHD8 p.R293K). Variants in these genes could cause antibody deficiency through inefficient $\mathrm{V}$ (D)J recombination, somatic hypermutation, and/or classswitch recombination. We did not find an association with variable genes and CVID phenotype (Fig. S1).

Every patient shared a variable gene with at least one other patient but no more than two variants with another (Table 1, Table S5). The most frequent variant in the cohort, POLR2B p.L522F, was found in six patients. PID017 and PID056 shared the two novel variants in MRE11A, p.Q582H, and p.G581R (Table 1).

\section{Altered Expression of Genes Related to DNA Repair in Complex CVID Patients}

We assessed the mRNA expression of 90 genes related to DNA repair in PBMC lysates (Fig. 2a-e).

Expression of ERCC2 was higher in CVID patients versus controls (Fig. 2a) and in complex versus infections-only patients (Fig. 2c). We did not find statistically significant differences in gene expression between infections-only CVID patients and controls (Fig. 2b). In complex patients, compared to controls, we found decreased expression of MSH6 and TREXI (Fig. 2c, e) and compared to infections-only patients, increased expression of TOP $3 A$ and $R A D 23 B$ and decreased expression of PCNA, RPA3, XRCC2, and MSH6 (Fig. 2d). The associations with RPA3 and PCNA appear due to their elevated expression in one or two patient samples, rather than in the cohort as a whole (Fig. 2e). 
Fig. 1 CVID patients have rare germline variants in genes related to DNA repair pathways. Classification across the cohort of (a) variant classification, variant type, single nucleotide variant class (transition or transversion), the number of variants per sample, variant classification summary and the top 20 frequently mutated genes. In the oncoplot (b), each row represents a gene, and each column a patient. The histogram summarises the number and type of variant per sample. In each row, the type of variant in a given gene is colour-coded with the $\%$ variability of that gene across the cohort a

Altered in $32(84.21 \%)$ of 38 samples.

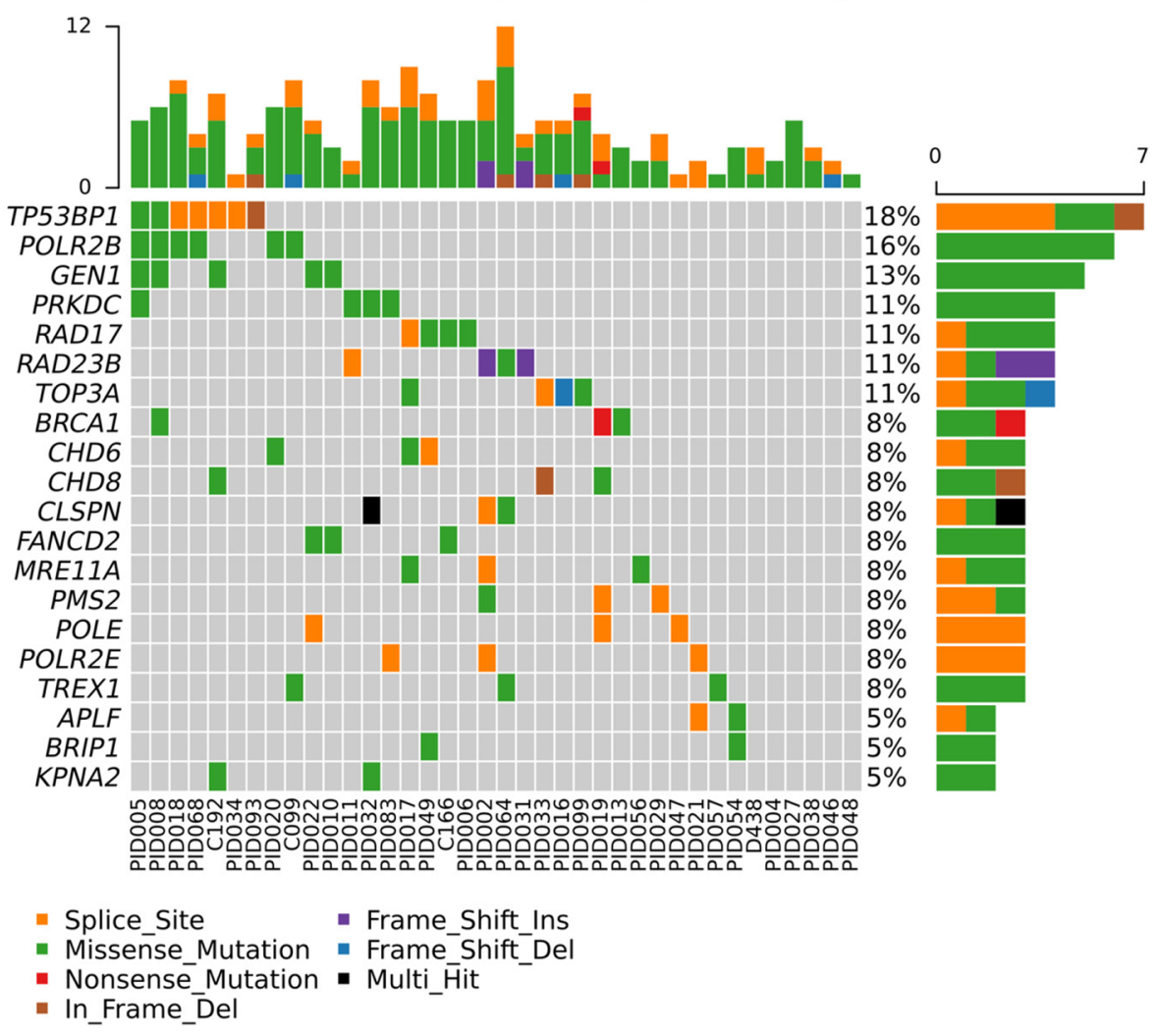

b

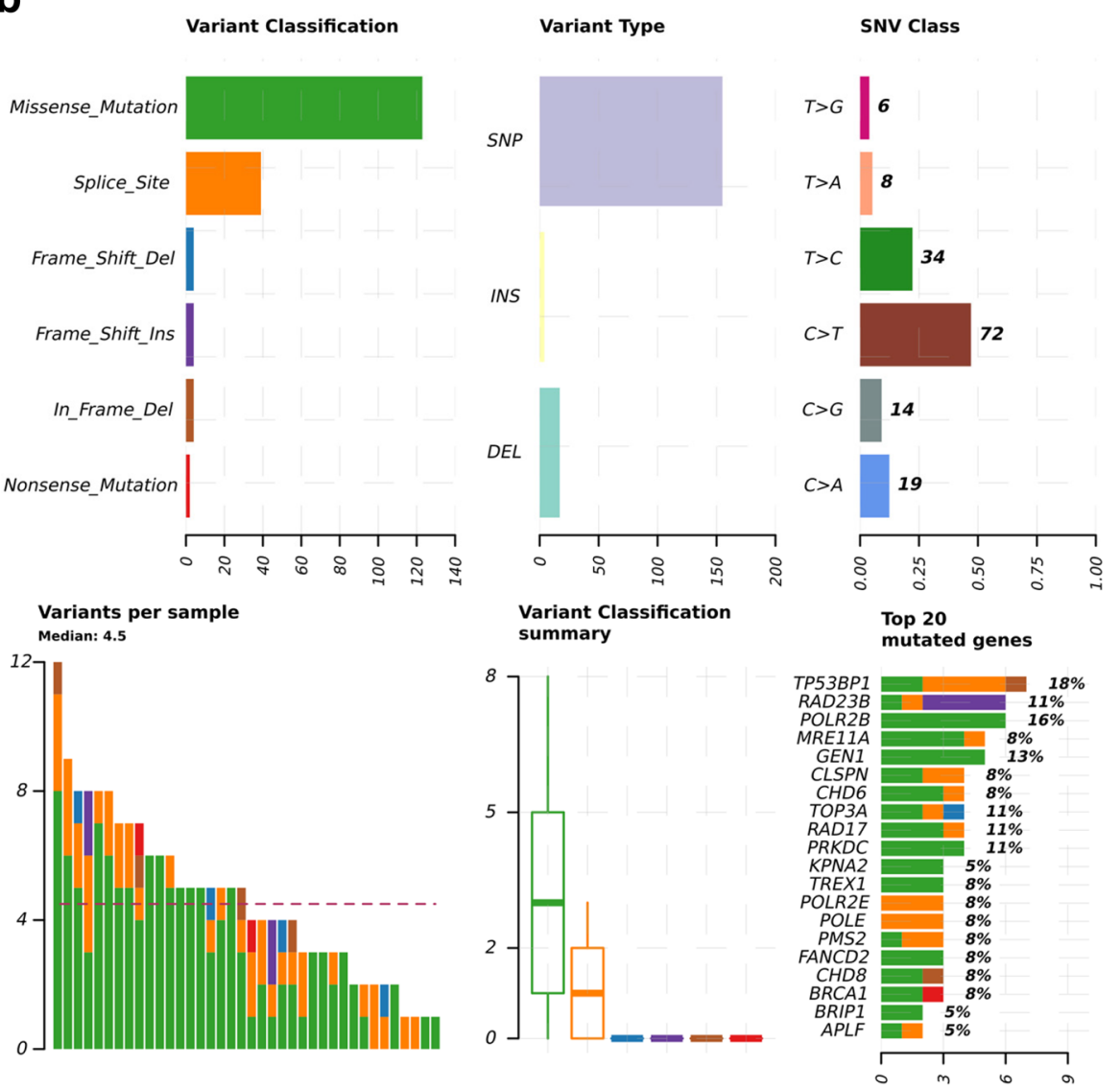


Alterations in gene expression in PBMCs could be a result of changes in cellular subfraction frequencies. We did not detect significant differences in the frequencies of $\mathrm{CD} 19^{+} \mathrm{B}$ cells, $\mathrm{T}$ cells $\left(\mathrm{CD} 3^{+}, \mathrm{CD} 4^{+}\right.$, and $\mathrm{CD} 8^{+}$), and $\mathrm{CD} 16^{+} \mathrm{CD} 56^{+} \mathrm{NK}$ cells, as measured by TBNK assay, between CVID phenotypic sub-groups (Fig. S2), and few were outside reference ranges (Fig. S3). There was a positive association between ERCC2 $\log ^{2}$ counts and NK cell frequencies $(r=0.58$, $p=0.009)$ and a negative correlation with $\mathrm{CD}^{+} \mathrm{T}$ cell frequencies $(r=-0.51, p=0.03)$. TREX1 expression was positively correlated with $\mathrm{CD} 4^{+} \mathrm{T}$ cell frequencies $(r=0.6, p=0.007)$ and negatively correlated with $\mathrm{CD}^{+} \mathrm{T}$ cell frequencies $(r=-0.54, p=0.02)$. We did not observe a significant correlation with the other genes examined (Fig. S3).

\section{CVID Patients Have Increased Levels of $\mathrm{\gamma H} 2 \mathrm{AX}$ Compared to Controls}

We measured $\gamma \mathrm{H} 2 \mathrm{AX}$ kinetics in PBMCs from controls and patients by flow cytometry. A representative gating strategy of immune cell subsets is shown in Fig. S4.

Patients had higher baseline frequencies of $\gamma \mathrm{H} 2 \mathrm{AX}^{+}$ cells than controls following $1 \mathrm{~h}$ in culture in $\mathrm{CD} 4^{+} \mathrm{T}$ cells $(p=0.0002), \mathrm{CD} 8^{+} \mathrm{T}$ cells $(p \leq 0.0001)$, and $\mathrm{CD} 19^{+} \mathrm{B}$ cells $(p \leq 0.0001)$ and at $24 \mathrm{~h}$ in CD $4^{+} \mathrm{T}$ cells $(p \leq 0.0001)$, $\mathrm{CD}^{+} \mathrm{T}$ cells $(p=0.0005)$, and $\mathrm{CD} 19^{+} \mathrm{B}$ cells $(p=0.0034)$ (Fig. S5).

Among CD19 ${ }^{+} \mathrm{B}$ cells, we observed a higher frequency of $\gamma \mathrm{H} 2 \mathrm{AX}^{+}$cells at $24 \mathrm{~h}$ in patients versus controls $(p=0.044)$, but not at $1 \mathrm{~h}$ post-irradiation (Fig. 3a, b). For $\mathrm{CD}^{+} \mathrm{T}$ cells, patient cells displayed increased frequencies of $\gamma \mathrm{H} 2 \mathrm{AX}^{+}$cells compared to controls $1 \mathrm{~h}(p \leq 0.0001)$ and $24 \mathrm{~h}$ post-irradiation $(p \leq 0.0001)$ (Fig. 3c, d). Similarly, for CD $8^{+} \mathrm{T}$ cells, $1 \mathrm{~h}(p=0.0004)$ and 24 h post-irradiation ( $p=0.04$ ) (Fig. 3e, f). No difference was observed between patient phenotypic subgroups for any of the lymphocyte subsets examined. Nor was increased $\gamma \mathrm{H} 2 \mathrm{AX}$ observed for the PAD patients. To assess DNA repair capacity, we measured the percent change from 1- to 24-h post-damage. Repair was significantly delayed in CVID CD4 $4^{+}(p=0.02)$ and CD $19^{+}$ $(p=0.05)$ cells. There was no significant delay in the clearance of $\mathrm{CD}^{+} \gamma \mathrm{H} 2 \mathrm{AX}^{+}$cells $(p=0.31)$, likely due to heterogeneity among control cells (Fig. 3g).

An accumulation of DNA damage is reported in aging memory $\mathrm{T}$ cells over naïve cells due to the increasing presence of terminally differentiated, senescent, and chronically antigen-activated T cells [33-35]. At $24 \mathrm{~h}$ post-irradiation, we observed a positive association with T cell $\gamma \mathrm{H} 2 \mathrm{AX}$ levels and increasing age of participants (Fig. S6) but not the other markers and cell types.

\section{A Subset of CVID Patients' B Cells Downregulates pATM $24 \mathrm{~h}$ Post-DNA Damage}

Activation of ATM is key to orchestrating DDR responses, including phosphorylating downstream effectors, regulation of the cell cycle, and initiating apoptosis [36]. We measured pATM levels among lymphocyte subsets by flow cytometry (Fig. 4a). At baseline (Fig. S5), B cells had decreased pATM compared to controls $(p \leq 0.001)$, likely due to apoptosis following time in culture. We did not observe differences in pATM expression in $\mathrm{CD} 19^{+} \mathrm{B}$ cells, $\mathrm{CD} 4^{+} \mathrm{T}$ cells or $\mathrm{CD} 8+\mathrm{T}$ cells between patients and controls or patient sub-groups $1 \mathrm{~h}$ post-irradiation (Fig. $4 \mathrm{~b}-\mathrm{d}$ ). However, $24 \mathrm{~h}$ post-DNA damage, there was a significant downregulation in pATM in CVID B cells $(p=0.03), \mathrm{CD}^{+} \mathrm{T}$ cells $(p=0.003)$, and a trend in $\mathrm{CD}^{+} \mathrm{T}$ cells $(p=0.09)$ compared to controls (Fig. 4b-d). There was a trend to a greater decrease in pATM in complex CVID patient $\mathrm{CD} 4^{+} \mathrm{T}$ cells compared to infections-only cells ( $p=0.05$; Fig. $4 c)$. The decrease in CVID B cell pATM levels was driven by $n=12 / 38$ patients, five with an infections-only phenotype and seven a complex phenotype.

The p53-binding protein 1 (53BP1), a crucial component of DSB repair downstream of ATM, influences cells' choice of the NHEJ pathway [37]. There was increased $\mathrm{CD}^{+}$cell expression of 53BP1 in CVID patients compared to controls $1 \mathrm{~h}$ following irradiation $(p=0.007)$ and a trend for $\mathrm{CD} 8^{+}$ cells $(p=0.06)$ (Fig. S7). There was decreased expression at baseline in CVID patient cells $\left(\mathrm{CD} 19^{+} p=0.02, \mathrm{CD} 4^{+}\right.$ $p=0.009$, and $\mathrm{CD}^{+} p=0.003$ ) compared to controls at $1 \mathrm{~h}$ (Fig. S5).

There was a positive correlation between the frequency of $\mathrm{CD}_{19}{ }^{+} \mathrm{pATM}^{+}$cells and CD $19^{+} 53 \mathrm{BP} 1^{+}$cells $(r=0.82$, $p=0.003) \mathrm{b}$ ut not with $\mathrm{CD} 19^{+} \gamma \mathrm{H} 2 \mathrm{AX}^{+}$cells $(r=0.29$, $p=0.39$ ) (Fig. 4e-f). We designated patients as pATM ${ }^{\text {hi }}$ if their B cells had $>50 \% \mathrm{ATM}^{+}$cells and as $\mathrm{pATM}^{\mathrm{lo}}$ if samples had $<50 \%$ pATM $^{+}$cells $24 \mathrm{~h}$ post-irradiation. At $24 \mathrm{~h}$, compared to controls and pATM ${ }^{\text {hi }}$ cells, the pATM $^{\text {lo }}$ group had decreased 53BP1 ( $p=0.002$ and $p \leq 0.001$, respectively) (Fig. 4g) and increased $\gamma \mathrm{H} 2 \mathrm{AX}^{+}$cells (both $p \leq 0.001$ ) (Fig. 4h).

To determine whether the $\mathrm{ATM}^{\mathrm{lo}}$ patient groups were genetically distinct from the ATM ${ }^{\text {hi }}$ group, we compared the variable genes between both groups. There was $n=4$ shared genes, $n=48$ and $n=14$ unique to $\mathrm{ATM}^{\text {hi }}$ and $\mathrm{ATM}^{\mathrm{lo}}$ groups, respectively (Fig. S8a), and a median of 2.2 variants in the $\mathrm{ATM}^{\text {hi }}$ group and 1.2 in the $\mathrm{ATM}^{\mathrm{lo}}$ group. There was no significant difference in ATM expression, 

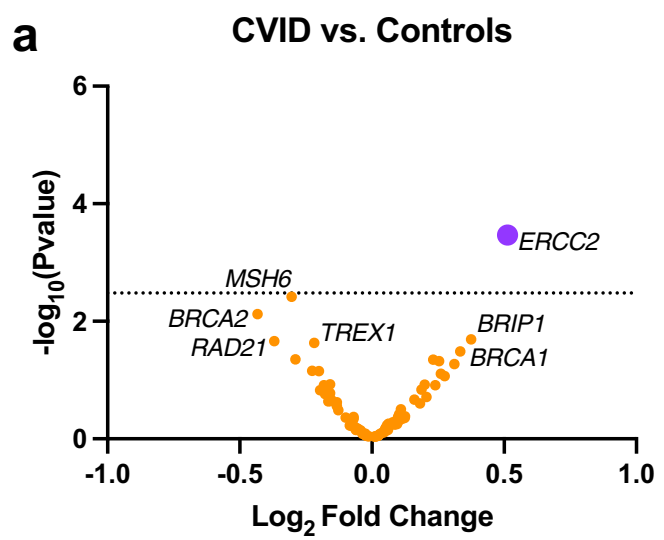

C Complex CVID vs. Controls

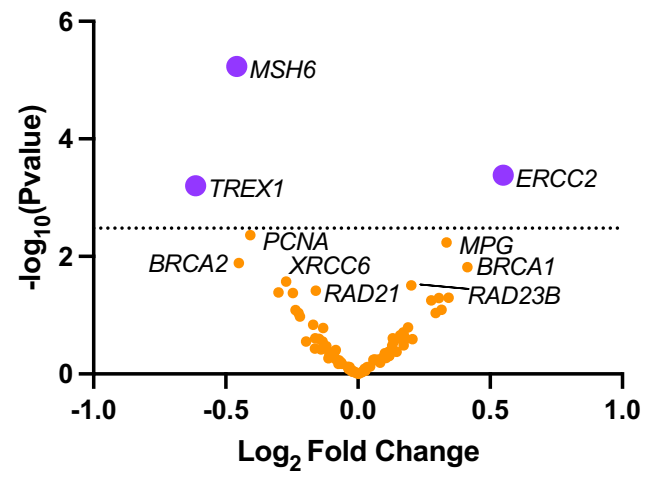

e

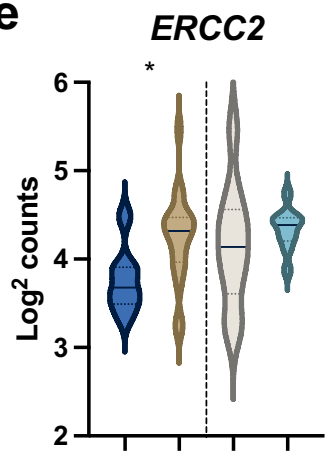

RPA3

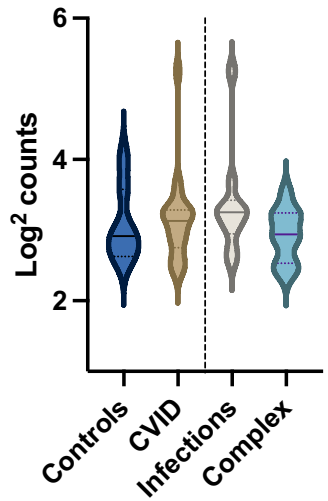

MSH6

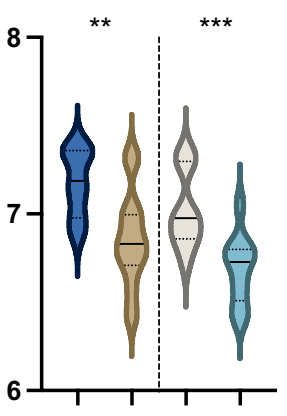

TOP3A

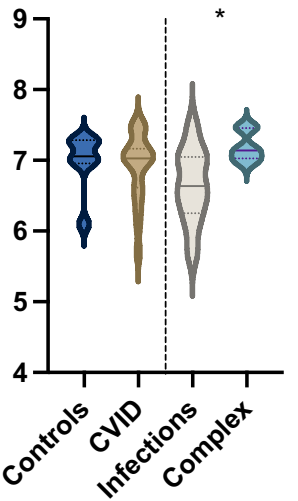

b Infections-only CVID vs. Controls

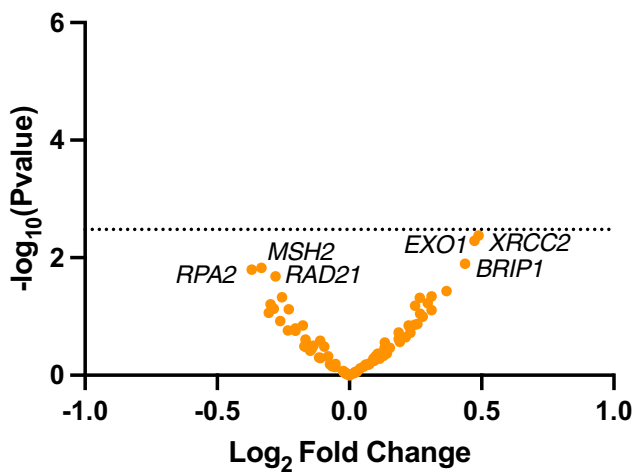

d Complex CVID vs. Infections-only CVID

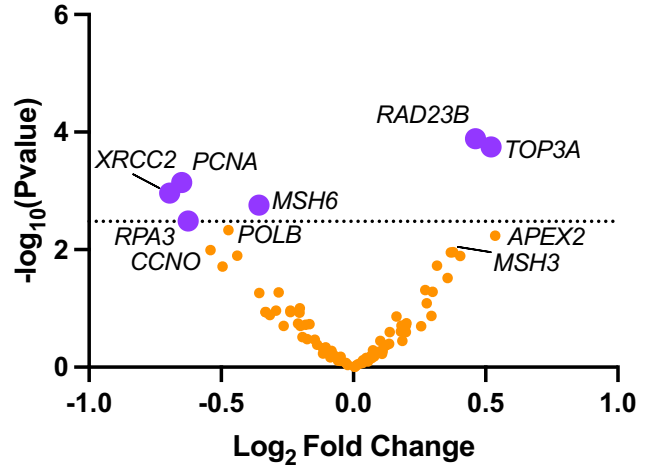

PCNA

RAD23B

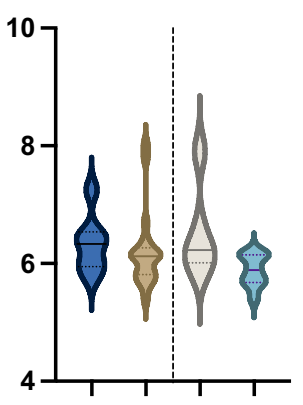

TREX1

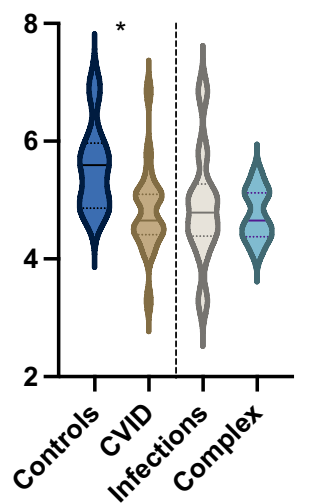

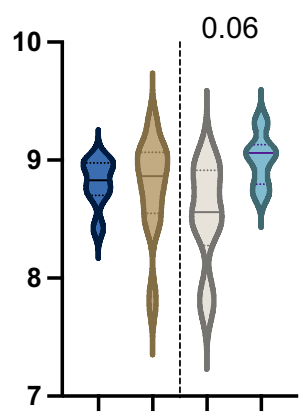

XRCC2

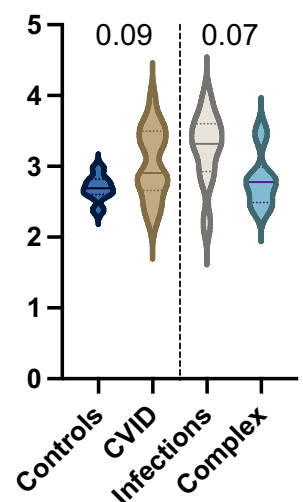


4Fig. 2 Differential gene expression of genes related to DNA repair pathways is altered in complex patients versus controls and infections-only patients. Volcano plots summarising the differential gene expression between (a) $n=20$ patients and $n=7$ controls, (b) $n=10$ infection-only phenotype versus controls, (c) $n=10$ complex phenotype patients versus controls and (d) complex phenotype patients versus infections-only patients. Genes whose expression is significantly different are shown in purple. The dotted line represents a false discovery rate $<0.05$. (e) Key genes and their $\log ^{2}$ counts are summarised in controls, patients and their phenotypic subgroups. Statistical significance is measured by Mann-Whitney test

but there was a trend of higher expression of $L I G 4$ and $R A D 23 B$ in $\mathrm{ATM}^{\mathrm{lo}}$ samples (both $p=0.06$ ) (Fig. S8b). However, significance was lost upon correction for multiple testing.

\section{Immune Cells from a Subset CVID Patients Have Increased Spontaneous and DNA Damage-Induced Apoptosis}

Given the mutagenic potential of unresolved DNA lesions, severe, or unrepaired DNA damage should trigger apoptosis [38]. We measured caspase-3's substrate, poly (ADPribose) polymerase (PARP). Cleaved PARP helps cells maintain viability, and its cleavage by caspase-3 is considered a hallmark of apoptosis [39, 40].

CVID $\mathrm{T}$ cells displayed increased basal and DNA damage-induced apoptosis, compared to controls (Fig. S9). We found increased spontaneous cleaved PARP expression in CVID patient B cells compared to controls at $1 \mathrm{~h}$ and $24 \mathrm{~h}$ post-irradiation ( $p \leq 0.00$ and $p=0.002$, respectively) and following irradiation ( $p=0.002$ and $p=0.04$, respectively) (Fig. 5a, b). This was particularly evident $24 \mathrm{~h}$ post-DNA damage induction, where a sub-group of CVID patients had significantly increased apoptosis, suggesting a role for the DNA damage response (Fig. 5b).

The frequencies of cleaved $\mathrm{PARP}^{+}$cells were negatively correlated with the frequency of $\mathrm{ATM}^{+}$cells ( $r=-0.95, p \leq 0.001$ ) (Fig. 5c). We analyzed the frequencies of cleaved PARP ${ }^{+} \mathrm{B}$ cells among $\mathrm{ATM}^{\text {lo }}$ and $\mathrm{ATM}^{\text {hi }}$ groups. The $\mathrm{ATM}^{\text {lo }}$ group had higher frequencies of cleaved PARP $^{+}$cells compared to controls at $1 \mathrm{~h}$ $(p=0.0074)$ and $24 \mathrm{~h}(p \leq 0.0001)$ and ATM $^{\text {hi }}$ cells at $1 \mathrm{~h}(p=0.0044)$ and $24 \mathrm{~h}(p \leq 0.0001)$ post-irradiation (Fig. 5d).

\section{Discussion}

While low or absent immunoglobulins are a hallmark feature of CVID and predispose to recurrent infections, patients are also at greater risk of malignancy than the general population $[21,41]$. In vitro radiosensitivity was first reported in CVID in the 1990s [42]. Polymorphisms in genes related to mismatch repair have been found at higher frequencies in an adult CVID cohort and a selective IgA deficiency cohort compared to controls and resulted in increased radiosensitivity in vitro in patient-derived and transfected cell lines [43]. Our WGS study found rare and novel variants in genes involved in $\mathrm{V}(\mathrm{D}) \mathrm{J}$ recombination and DNA repair [8]. We hypothesized that multiple heterozygous variants in DNA repair genes, which individually would have a small effect size, combine in distinct or overlapping pathways to predispose to sporadic CVID and its complications. We applied a targeted approach to understanding the genetic and cellular responses of DNA repair in CVID.

The most frequently variable gene, TP53BP1, was found to have four variants in seven patients. Minimal sharing of variable genes was observed between patients, fitting a polygenic model. As in Offer et al. [43], our cohort included variants in $M L H 3, M S H 3$, and MRE11A. We identified 15 novel variants in known PID genes: AICDA, ATM, DCLRE1C, CHD7, PRKDC, RAG1, and RNF168. A GWAS of CVID found that many of the identified variants were unique to individual patients [7] and recent whole exome sequencing uncovered mostly novel rather than published variants [44].

The variants reported here are heterozygous, which is perhaps unsurprising as monogenic DNA repair conditions were not suspected clinically. Heterozygous variants of interest are reported in other sequencing studies of CVID cohorts [44, 45]. Genetic complexity in a predominantly sporadic condition like CVID could also be driven by non-coding regions, epistatic interactions, and incomplete penetrance. Functional validation of genetic candidates is further complicated by differing clinical presentations among family members with the same variant [46]. Careful selection of variants for functional follow-up in models incorporating multiple variants is needed for a complete picture of CVID pathogenesis.

We assessed differential expression of genes related to DNA repair in PBMCs from CVID patients and controls, anticipating subtle changes in expression. In comparing patients and controls, we observed increased expression of nucleotide excision repair factor, ERCC2. The gene product of ERCC2, XPD, is involved in transcriptioncoupled nucleotide excision repair, and increased expression has been associated with chemoresistance to cisplatin [47] and colorectal cancer [48]. No genes were found to be differentially expressed between infections-only CVID patients and controls. Complex CVID patients had decreased expression of MSH6 and TREX1 compared to both controls and infections-only CVID patients. MSH6 is a component of mismatch repair, and TREX1 is an 
Fig. 3 CVID B and T cells have higher levels of the DDR marker, $\gamma \mathrm{H} 2 \mathrm{AX}$, than controls. PBMCs from controls $(n=11)$ and CVID and PAD patients ( $n=34$ and $n=2$, respectively) were analysed by flow cytometry. a, c, e Representative histograms of intra-nuclear gH2AX expression after 1 and 24h of culture in CD19+ $\mathrm{B}$ cells, $\mathrm{CD}^{+}{ }^{+} \mathrm{T}$ cells and $\mathrm{CD} 8^{+} \mathrm{T}$ cells. Untreated cells are shown in grey and cells exposed to $5 \mathrm{~Gy}$ g-irradiation in a control (blue) and CVID patient (gold). The frequency of $\mathrm{gH}_{2} \mathrm{AX}^{+}$cells in $\mathbf{b} \mathrm{CD} 19^{+} \mathrm{B}$ cells, $\mathbf{c ~ C D} 4^{+}$ $\mathrm{T}$ cells and $\mathbf{d} \mathrm{CD} 8^{+} \mathrm{T}$ cells 1 and 24 h post-irradiation. Displayed are controls (circles), CVID patients (squares), CVID patients with an infections-only phenotype (triangles, $n=19$ ) and CVID patients with a complex phenotype (diamonds, $n=15$ ). e The $\%$ of DNA repair presented as the change in $\mathrm{gH}_{2} \mathrm{AX}^{+}$ cell frequency from 1 to $24 \mathrm{~h}$ post-irradiation. Each symbol represents an individual control or patient. Bar represents the median. Statistical significance was determined by MannWhitney test
Untreated

a $\quad$ CD19+ $B$ cells

b

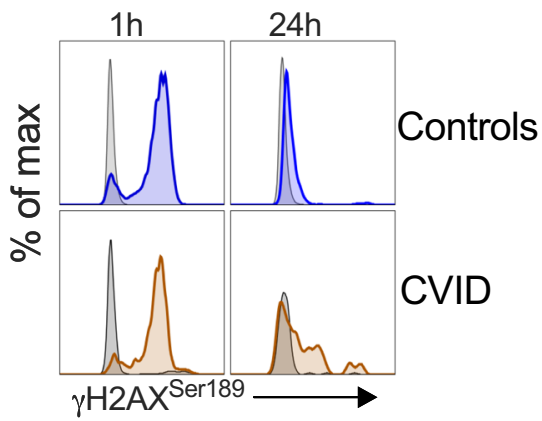

C $\mathrm{CD}^{+} \mathrm{T}$ cells

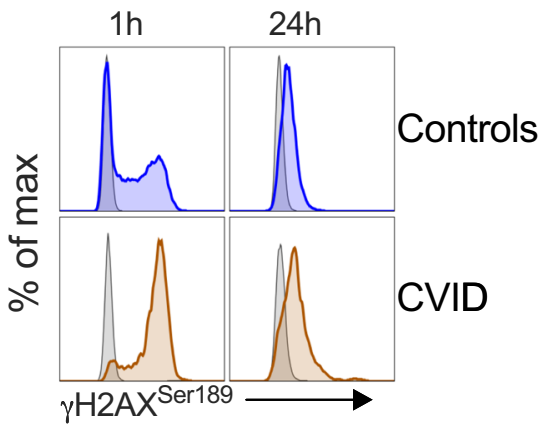

e

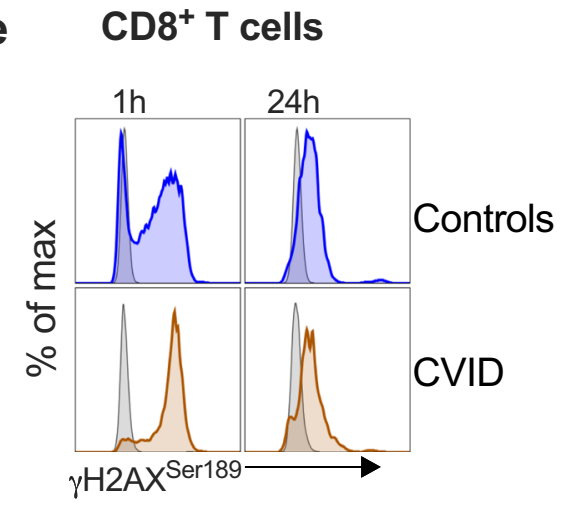

d

f
$24 h$ post-irradiation
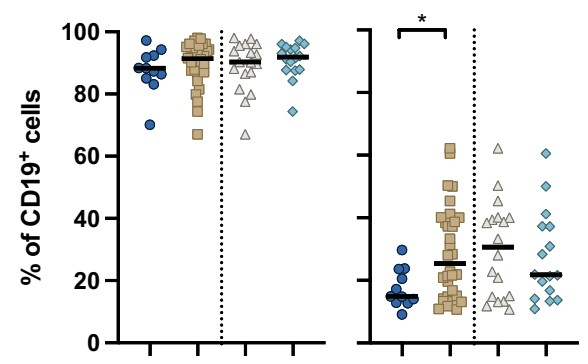
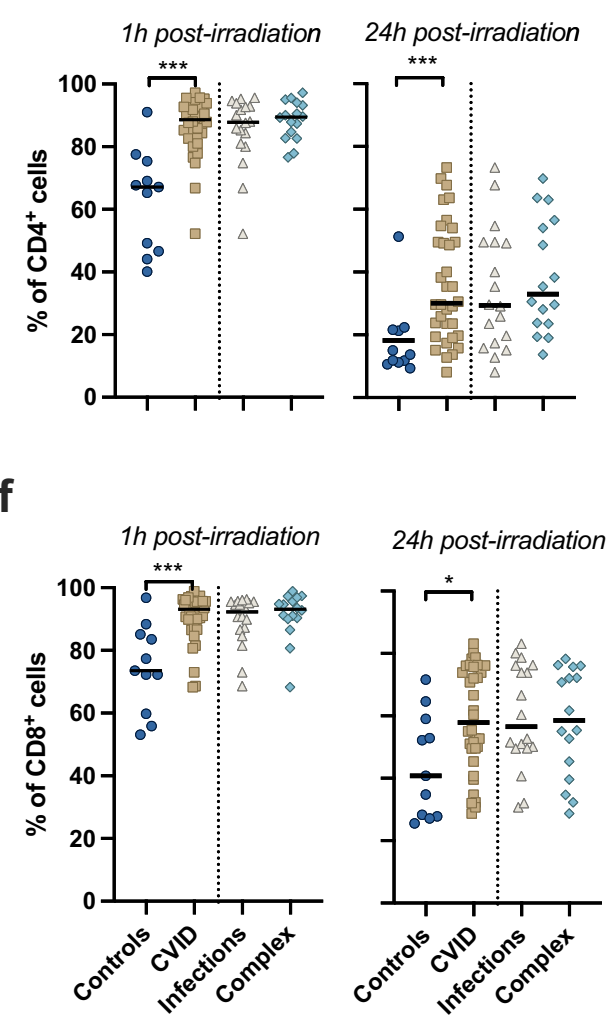

$C D 8$

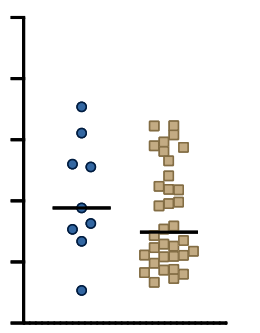

- Controls

- CVID 
intracellular exonuclease that degrades single- and doublestranded DNA in the cytoplasm [49] and is of interest in CVID given the elevated DNA damage and apoptosis we observe in this cohort. When comparing between CVID patient sub-groups, only those with a complex phenotype displayed increased expression of TOP3A, a DNA topoisomerase that controls the topology of DNA during replication and transcription. Increased mRNA expression of TOP3A is correlated with worse prognosis in non-smallcell lung cancer and lung adenocarcinomas [50].

A caveat to using PBMCs is cell type-specific effects may be diluted. Further analysis should focus on cell subsets given the documented perturbations in CVID B and $\mathrm{T}$ cell memory subset frequencies [51-55] and differences in methylation states in the naïve to memory B cell transition in CVID which affect transcriptional activity [56]. Additionally, some transcriptional changes may only become apparent upon stimulation.

A DNA repair defect was proven in some CVID patients with a homozygous stop codon in NHEJl by measurement of $\gamma \mathrm{H} 2 \mathrm{AX}$ by microscopy and flow cytometry [57]. We found a greater induction of DNA damage following irradiation and delayed repair in a subset of patients, suggesting a failure of DNA repair machinery. The observed association of elevated $\mathrm{T}$ cell $\gamma \mathrm{H} 2 \mathrm{AX}$ expression and increasing age may be due to increased terminally differentiated effector T cells in CVID [58]. The controls included in this study are younger than patients due to local availability of donors. Further studies should feature more closely age-matched controls.

Following irradiation, a profound decrease in PATM was observed in a subset of CVID B cells. Cells with the lowest pATM levels also had decreased 53BP1 and higher $\gamma \mathrm{H} 2 \mathrm{AX}$ as compared to controls and other patients. The deficiency of pATM we observe in CVID B cells does not result in the neurodegenerative phenotype found in ataxia telangiectasia, so this is a less severe dysfunction and may reflect immune cell-specific deficiency. Recent evidence has implicated DDR pathways in inflammation [10,59] and rheumatoid arthritis [60-63]. In rheumatoid arthritis T cells, reduced ATM was identified at baseline [63]. ATM deficiency prevented $\mathrm{T}$ cell proliferation and promoted premature apoptosis [60, 61]. A failure to induce pATM in the rheumatoid arthritis B cells $1 \mathrm{~h}$ post-irradiation was associated with skewed kappa light chain usage and an increased prevalence of CD $21^{\text {lo }} \mathrm{B}$ cells, a subset associated with CVID [64]. It would be of interest to study the role of ATM biology in CVID patients with greater proportions of $\mathrm{CD} 21^{\text {lo }} \mathrm{B}$ cells and according to Paris [55], Freiburg [54], and EUROClass [53] groups. Inflammatory processes can damage DNA [65-67]. While we cannot preclude that the DNA damage we observe is a result of inflammation rather than genetics, it is unlikely given that we do not observe differences between CVID patients with inflammatory complications and those without and samples were taken when disease was stable.

The low B cell numbers in some patients and the failure of naïve to memory transition may be due to increased susceptibility for apoptosis. Indeed, our previous RNAseq data [8] found elevated FAS gene expression in CVID B cells, and increased spontaneous apoptosis of CVID memory B cells has been shown in vitro $[68,69]$. We measured the caspase-3 substrate, cleaved PARP, as an early marker of apoptosis at baseline and following irradiation. CVID T cells showed increased basal and induced levels of cleaved PARP, while CVID B cells had higher basal cleaved PARP, which further increased upon irradiation. These data are in accordance with other studies on apoptosis [69-72] and, given the association with decreased ATM, proposes deficient DNA repair as its mechanism.

\section{Conclusions}

In conclusion, we identified rare and novel variants in genes related to DNA repair in a cohort of patients with sporadic CVID. The differential expression of genes TOP $3 A$, $X R C C 2$, and MSH6 distinguishes patients with a complex CVID phenotype from those with an infections-only CVID phenotype and controls. Decreased pATM impairs the recruitment of other repair factors, delays damage repair and promotes apoptosis. Understanding the mechanism of antibody failure and malignancy risk in patients with complex CVID will aid clinical management and therapeutic development.

Supplementary Information The online version contains supplementary material available at https://doi.org/10.1007/s10875-021-01050-2.

Acknowledgements We would like to thank the patients and their families for taking part in this study. We gratefully acknowledge Dr. Siraj Misbah, Dr. Rashmi Jain and the clinical immunology nursing team for patient sample collection and TGU investigators for control sample collection, Dr Helen Ferry and the Nuffield Department of Medicine Experimental Medicine flow cytometry core facility, Dr Joanna Hester (Nuffield Department of Surgery), Dr Alex Adams (Nuffield Department of Medicine), Jim White at NanoString and Professor Helen Chapel for critical reading of the manuscript. The views expressed are those of the authors and not necessarily those of the NHS, the NIHR, or the Department of Health.

Authors' Contributions CEH and SYP designed experiments and wrote the manuscript. CEH and AMP conducted experiments. CEH analyzed data and designed figures. SS and JB performed bioinformatics analyses and designed figures. SCS, JEGC, EB, and CA collected clinical and laboratory information. JCK and SYP directed the study. All authors critically reviewed and edited the manuscript.

Funding This study was funded by a Wellcome Trust Seed Award $(109692 / Z / 15 / Z)$ (SYP), a University of Oxford Medical Sciences 
Untreated
a Irradiated

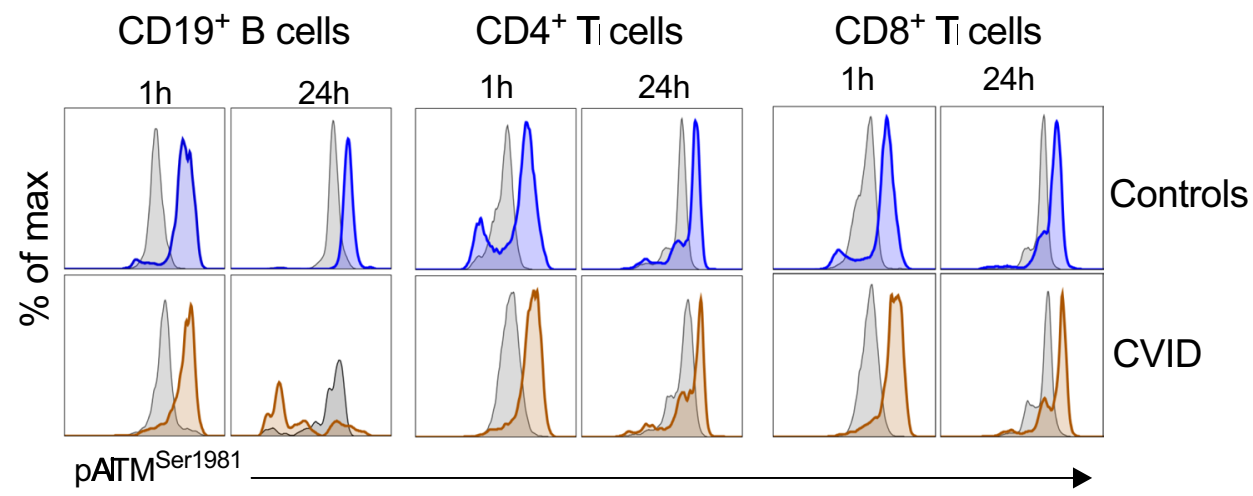

- Controls $\square$ CVID $\triangle$ Infections-only $\diamond$ Complex

b

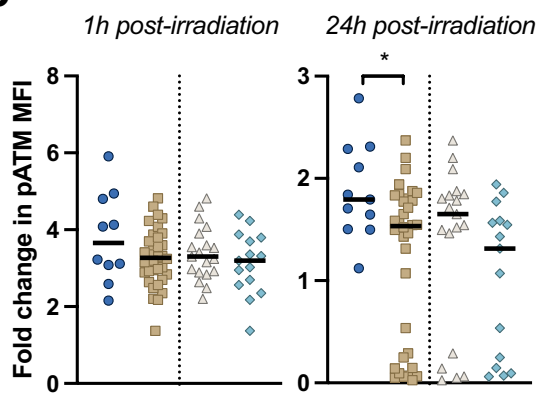

C

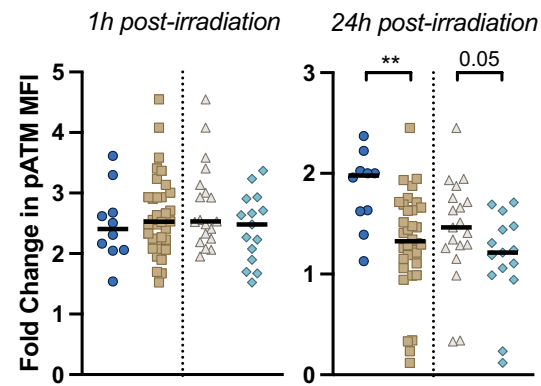

d

1h post-irradiation $24 \mathrm{~h}$ post-irradiation

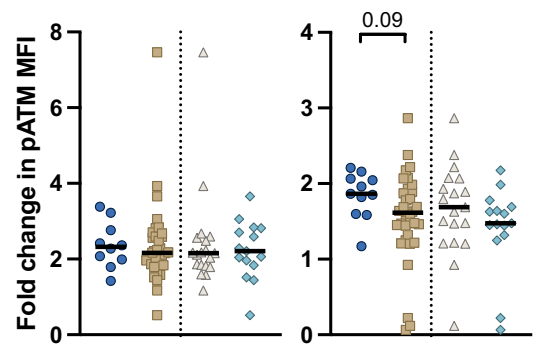

e

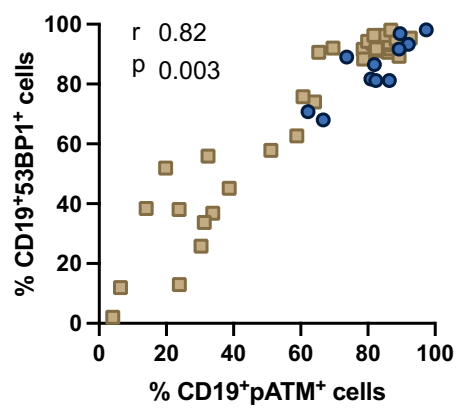

g

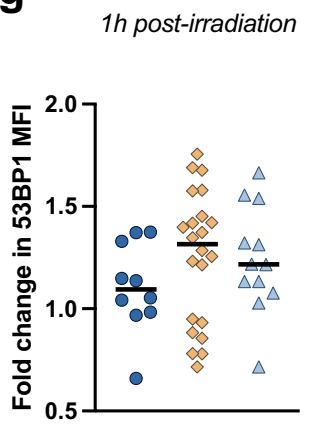

$24 h$ post-irradiation

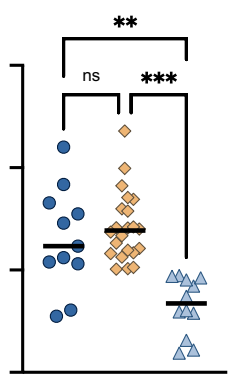

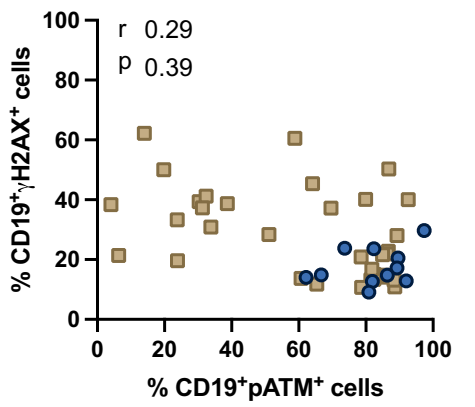

- Controls

CVID

h

1h post-irradiation $24 \mathrm{~h}$ post-irradiation

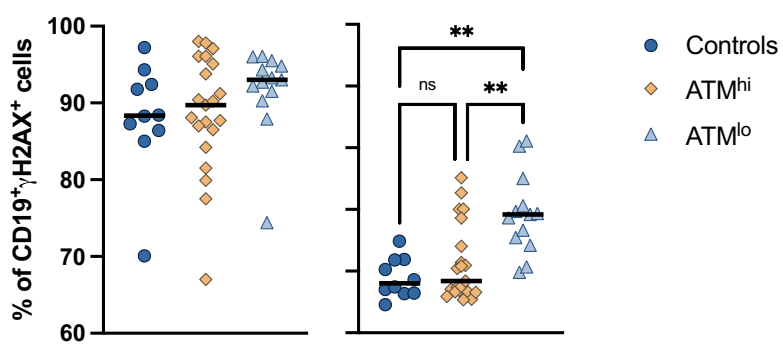


4Fig. 4 A subset of CVID patients' B cells downregulate pATM $24 \mathrm{~h}$ after DNA damage. (a) Representative histograms of intra-nuclear pATM expression after 1 and $24 \mathrm{~h}$ of culture in $\mathrm{CD} 19^{+} \mathrm{B}$ cells, $\mathrm{CD} 4^{+} \mathrm{T}$ cells and $\mathrm{CD}^{+} \mathrm{T}$ cells. Untreated cells are shown in grey and cells exposed to 5 Gy g-irradiation in a control and CVID patient in bold. The fold change in median fluorescence over untreated cells is shown for (b) $\mathrm{CD} 19^{+} \mathrm{B}$ cells, (c) $\mathrm{CD}^{+} \mathrm{T}$ cells and (d) $\mathrm{CD} 8^{+} \mathrm{T}$ cells 1 and $24 \mathrm{~h}$ post-irradiation. Displayed are controls (circles, $\mathrm{n}=11$ ), CVID and PAD patients (squares, $\mathrm{n}=34$ ), CVID patients with an infections-only phenotype (triangles, $\mathrm{n}=19$ ) and CVID patients with a complex phenotype (diamonds, $\mathrm{n}=15$ ). Bar represents the median. Statistical significance was determined by Mann-Whitney test. Spearman rank correlations of the frequency of $\mathrm{CD}_{1} 9^{+} \mathrm{pATM}^{+}$cells and frequencies of (e) $\mathrm{CD} 19^{+} 53 \mathrm{BP} 1^{+}$cells and (f) $\mathrm{CD}_{19^{+}} \mathrm{gH} 2 \mathrm{AX}^{+}$cells. CVID samples were classified as $\mathrm{ATM}^{\mathrm{hi}}$ or $\mathrm{ATM}^{\mathrm{lo}}$ based on their B cell pATM expression $24 \mathrm{~h}$ post-irradiation. For $\mathrm{B}$ cells, the (g) fold change of 53BP1 over untreated and (h) frequency of $\mathrm{gH}_{2} \mathrm{AX}^{+}$cells were compared amongst controls (circles), $\mathrm{ATM}^{\mathrm{hi}}$ (diamonds, $\mathrm{n}=21$ ) and $\mathrm{ATM}^{\mathrm{lo}}$ (triangles, $\mathrm{n}=13$ ) groups. Statistical significance was determined by two-way ANOVA with Tukey's test for multiple comparisons. Each symbol represents an individual control or patient.
Division Internal Fund award $(\mathrm{CEH})$ and a NanoString PlexSet ${ }^{\mathrm{TM}}$ Gene Expression Pathway Panel Grant (CEH). SYP is funded by the NIHR Biomedical Research Centre Oxford. SS, JB and core facilities at the Wellcome Centre for Human Genetics, including the HighThroughput Genomics Group, were supported by the Wellcome Trust 203141/Z/16/Z and the NIHR Oxford BRC. SCS is supported by an Oxford-BMS Fellowship. JCK is supported by a Wellcome Trust Investigator Award (204969/Z/16/Z) and NIHR Oxford.

Data Availability Upon request.

Code Availability Upon request.

\section{Declarations}

Ethics Approval The study was approved by the South Central Research Ethics Committee approval (12/SC/0044) and the Oxford Gastrointestinal Illness Biobank (16/YH/0247). Studies were performed according to the Declaration of Helsinki. a

\section{Untreated \\ Irradiated}
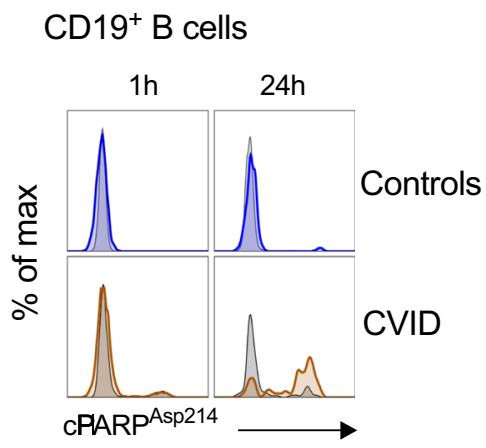

C

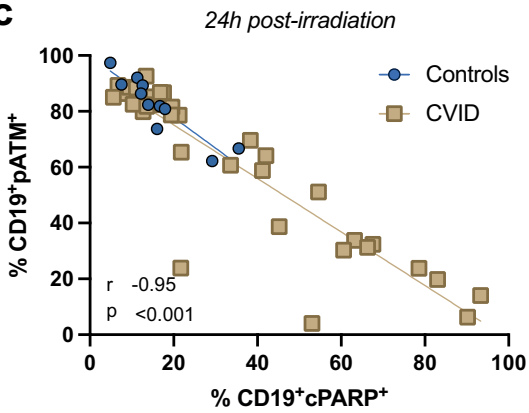

Fig. 5 CVID B cells display increased apoptosis which is inversely correlated with pATM levels. a Representative gating of early apoptotic marker, $\mathrm{cPARP}^{+}$, after 1 and $24 \mathrm{~h}$ of culture in $\mathrm{CD} 19^{+} \mathrm{B}$ cells. Untreated cells are shown in grey and cells exposed to $5 \mathrm{~Gy}$ g-irradiation in a control and CVID patient in bold. b Frequency of $\mathrm{CD} 19^{+} \mathrm{CPARP}^{+}$cells in (circles, $n=11$ ), CVID and PAD patients (squares, $n=34$ ), CVID patients with an infections-only phenotype (triangles, $\mathrm{n}=19$ ) and CVID patients with a complex phenotype diamonds, $\mathrm{n}=15$ ). Statistical significance was deter- b

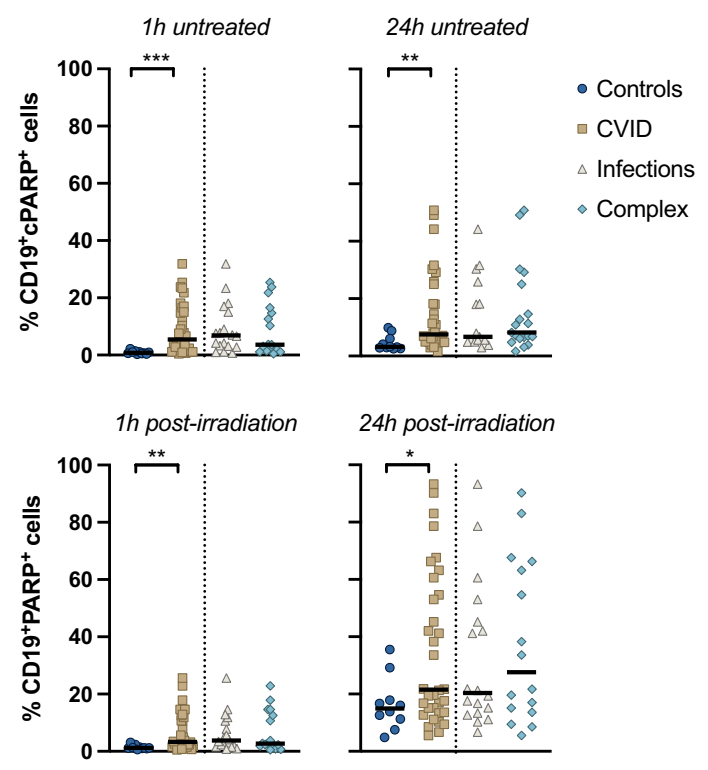

d

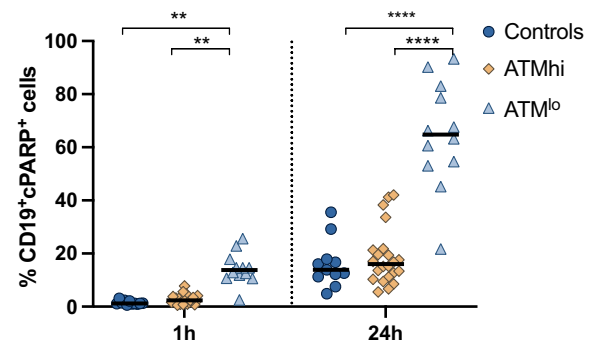

mined by Mann-Whitney test. c Spearman rank correlations of $\mathrm{pATM}^{+}$ cells and $\mathrm{CPARP}^{+}$cells amongst $\mathrm{CD} 19^{+} \mathrm{B}$ cells. Each symbol represents an individual control or patient. d Frequency of CPARP $^{+}$cells following irradiation in $n=11$ controls (circles), $\mathrm{ATM}^{\text {hi }}$ (diamonds, $\mathrm{n}=22$ ) and $\mathrm{ATM}^{\mathrm{lo}}$ (triangles, $\mathrm{n}=12$ ) patient groups. Statistical significance was determined by two-way ANOVA with Tukey's test for multiple comparisons. Each symbol represents an individual control or patient. Bars represents the median. 
Consent to Participate All participants gave informed written consent.

Consent for Publication Obtained.

Conflict of Interest The authors declare no competing interests.

Open Access This article is licensed under a Creative Commons Attribution 4.0 International License, which permits use, sharing, adaptation, distribution and reproduction in any medium or format, as long as you give appropriate credit to the original author(s) and the source, provide a link to the Creative Commons licence, and indicate if changes were made. The images or other third party material in this article are included in the article's Creative Commons licence, unless indicated otherwise in a credit line to the material. If material is not included in the article's Creative Commons licence and your intended use is not permitted by statutory regulation or exceeds the permitted use, you will need to obtain permission directly from the copyright holder. To view a copy of this licence, visit http://creativecommons.org/licenses/by/4.0/.

\section{References}

1. Hammarstrom L, Vorechovsky I, Webster D. Selective IgA deficiency (SIgAD) and common variable immunodeficiency (CVID). Clin Exp Immunol. 2000;120(2):225-31. https://doi.org/10. 1046/j.1365-2249.2000.01131.x.

2. Conley ME, Dobbs AK, Farmer DM, Kilic S, Paris K, Grigoriadou S, et al. Primary B cell immunodeficiencies: comparisons and contrasts. Annu Rev Immunol. 2009;27:199-227. https://doi.org/ 10.1146/annurev.immunol.021908.132649.

3. Chapel H, Lucas M, Lee M, Bjorkander J, Webster D, Grimbacher $\mathrm{B}$, et al. Common variable immunodeficiency disorders: division into distinct clinical phenotypes. Blood. 2008;112(2):277-86. https://doi.org/10.1182/blood-2007-11-124545.

4. Resnick ES, Moshier EL, Godbold JH, Cunningham-Rundles C. Morbidity and mortality in common variable immune deficiency over 4 decades. Blood. 2012;119(7):1650-7. https://doi.org/10. 1182/blood-2011-09-377945.

5. Kienzler A, Hargreaves C, Patel S. The role of genomics in common variable immunodeficiency disorders. Clin Exp Immunol. 2017;188:326-32.

6. Tuijnenburg P, Lango Allen H, Burns SO, Greene D, Jansen MH, Staples E, et al. Loss-of-function nuclear factor kappaB subunit 1 (NFKB1) variants are the most common monogenic cause of common variable immunodeficiency in Europeans. J Allergy Clin Immunol. 2018;142(4):1285-96. https://doi.org/10.1016/j.jaci. 2018.01.039.

7. Orange J, Glessner J, Resnick E, Sullivan K, Lucas M, Ferry $\mathrm{B}$, et al. Genome-wide association identifies diverse causes of common variable immunodeficiency. J Allergy Clin Immunol. 2011;127(6):1360-U79. https://doi.org/10.1016/j.jaci.2011.02. 039.

8. van Schouwenburg P, Davenport E, Kienzler A, Marwah I, Wright B, Lucas M, et al. Application of whole genome and RNA sequencing to investigate the genomic landscape of common variable immunodeficiency disorders. Clin Immunol. 2015;160(2):301-14. https://doi.org/10.1016/j.clim.2015.05.020.

9. Bednarski JJ, Sleckman BP. At the intersection of DNA damage and immune responses. Nat Rev Immunol. 2019;19(4):231-42. https://doi.org/10.1038/s41577-019-0135-6.

10. Nakad R, Schumacher B. DNA Damage Response and Immune Defense: Links and Mechanisms. Front Genet. 2016;7:147. https:// doi.org/10.3389/fgene.2016.00147.
11. Zanotti KJ, Gearhart PJ. Antibody diversification caused by disrupted mismatch repair and promiscuous DNA polymerases. DNA Repair. 2016;38:110-6. https://doi.org/10.1016/j.dnarep.2015.11. 011.

12. Bak ST, Sakellariou D, Pena-Diaz J. The dual nature of mismatch repair as antimutator and mutator: for better or for worse. Front Genet. 2014;5:287. https://doi.org/10.3389/fgene.2014.00287.

13. Shiloh Y. ATM and related protein kinases: safeguarding genome integrity. Nat Rev Cancer. 2003;3(3):155-68. https://doi.org/10. 1038/nrc1011.

14. Jackson SP, Bartek J. The DNA-damage response in human biology and disease. Nature. 2009;461(7267):1071-8. https://doi.org/ 10.1038/nature08467.

15. Ciccia A, Elledge SJ. The DNA damage response: making it safe to play with knives. Mol Cell. 2010;40(2):179-204. https://doi. org/10.1016/j.molcel.2010.09.019.

16. Pilzecker B, Jacobs H. Mutating for good: DNA damage responses during somatic hypermutation. Front Immunol. 2019;10:438. https://doi.org/10.3389/fimmu.2019.00438.

17. Roa S, Li Z, Peled JU, Zhao C, Edelmann W, Scharff MD. MSH2/ MSH6 complex promotes error-free repair of AID-induced dU: $\mathrm{G}$ mispairs as well as error-prone hypermutation of A: T sites. PLoS ONE. 2010;5(6):e11182. https://doi.org/10.1371/journal. pone.0011182.

18. Slatter MA, Gennery AR. Primary immunodeficiencies associated with DNA-repair disorders. Expert Rev Mol Med. 2010;12:e9. https://doi.org/10.1017/S1462399410001419.

19. Roskin K, Simchoni N, Liu Y, Lee J, Seo K, Hoh R, et al. $\mathrm{IgH}$ sequences in common variable immune deficiency reveal altered B cell development and selection. Sci Transl Med. 2015;7(302):302ra135. https://doi.org/10.1126/scitranslmed. aab1216.

20. van Schouwenburg PA, IJspeert H, Pico-Knijnenburg I, Dalm V, van Hagen PM, van Zessen D, et al. Identification of CVID patients with defects in immune repertoire formation or specification. Front Immunol. 2018;9:2545. https://doi.org/10.3389/fimmu. 2018.02545.

21. Mellemkjaer L, Hammarstrom L, Andersen V, Yuen J, Heilmann C, Barington T, et al. Cancer risk among patients with IgA deficiency or common variable immunodeficiency and their relatives: a combined Danish and Swedish study. Clin Exp Immunol. 2002;130(3):495-500. https://doi.org/10.1046/j.1365-2249.2002. 02004.x.

22. Li H, Durbin R. Fast and accurate short read alignment with Burrows-Wheeler transform. Bioinformatics. 2009;25(14):1754-60. https://doi.org/10.1093/bioinformatics/btp324.

23. Rimmer A, Phan H, Mathieson I, Iqbal Z, Twigg SRF, Consortium WGS, et al. Integrating mapping-, assembly- and haplotype-based approaches for calling variants in clinical sequencing applications. Nat Genet. 2014;46(8):912-8. https://doi.org/10.1038/ng.3036.

24. McLaren W, Gil L, Hunt SE, Riat HS, Ritchie GRS, Thormann A, et al. The Ensembl variant effect predictor. Genome Biol. 2016;17(1):122. https://doi.org/10.1186/s13059-016-0974-4.

25. The Genomes Project Consortium, Auton A, Brooks LD, Durbin RM, Garrison EP, Kang HM, et al. A global reference for human genetic variation. Nature. 2015;526(7571):68-74. https://doi.org/ 10.1038/nature 15393.

26. UK10K Consortium, Walter K, Min JL, Huang J, Crooks L, Memari Y, et al. The UK10K project identifies rare variants in health and disease. Nature. 2015;526(7571):82-90. https://doi. org/10.1038/nature14962.

27. Landrum MJ, Lee JM, Benson M, Brown GR, Chao C, Chitipiralla $\mathrm{S}$, et al. ClinVar: improving access to variant interpretations and supporting evidence. Nucleic Acids Res. 2018;46(D1):D1062-7. https://doi.org/10.1093/nar/gkx1153. 
28. Salatino S, Ramraj V. BrowseVCF: a web-based application and workflow to quickly prioritize disease-causative variants in VCF files. Brief Bioinform. 2017;18(5):774-9. https://doi.org/10.1093/ bib/bbw054.

29. Mayakonda A, Lin DC, Assenov Y, Plass C, Koeffler HP. Maftools: efficient and comprehensive analysis of somatic variants in cancer. Genome Res. 2018;28(11):1747-56. https://doi. org/10.1101/gr.239244.118.

30. Richards S, Aziz N, Bale S, Bick D, Das S, Gastier-Foster J, et al. Standards and guidelines for the interpretation of sequence variants: a joint consensus recommendation of the American College of Medical Genetics and Genomics and the Association for Molecular Pathology. Genet Med. 2015;17(5):405-23. https://doi. org/10.1038/gim.2015.30.

31. Love MI, Huber W, Anders S. Moderated estimation of fold change and dispersion for RNA-seq data with DESeq2. Genome Biol. 2014;15(12):550. https://doi.org/10.1186/s13059-014-0550-8.

32. Karczewski KJ, Francioli LC, Tiao G, et al. The mutational constraint spectrum quantified from variation in 141,456 humans. Nature. 2020;581:434-43. https://doi.org/10.1038/ s41586-020-2308-7.

33. Callender LA, Carroll EC, Bober EA, Akbar AN, Solito E, Henson SM. Mitochondrial mass governs the extent of human T cell senescence. Aging Cell. 2020;19(2):e13067. https://doi.org/10. 1111/acel.13067.

34. Covre LP, Martins RF, Devine OP, Chambers ES, VukmanovicStejic M, Silva JA, et al. Circulating senescent T cells are linked to systemic inflammation and lesion size during human cutaneous leishmaniasis. Front Immunol. 2019;9:3001. https://doi.org/10. 3389/fimmu.2018.03001.

35. Ji Y, Dang X, Nguyen LNT, Nguyen LN, Zhao J, Cao D, et al. Topological DNA damage, telomere attrition and $\mathrm{T}$ cell senescence during chronic viral infections. Immun Ageing. 2019;16(1):12. https://doi.org/10.1186/s12979-019-0153-z.

36. Tanaka T, Huang X, Halicka HD, Zhao H, Traganos F, Albino AP, et al. Cytometry of ATM activation and histone H2AX phosphorylation to estimate extent of DNA damage induced by exogenous agents. Cytometry A. 2007;71A(9):648-61. https://doi.org/ 10.1002/cyto.a.20426.

37. Panier S, Boulton SJ. Double-strand break repair: 53BP1 comes into focus. Nat Rev Mol Cell Biol. 2014;15(1):7-18. https://doi. org/10.1038/nrm3719.

38. Roos W, Thomas A, Kaina B. DNA damage and the balance between survival and death in cancer biology. Nat Rev Cancer. 2016;16:20-33. https://doi.org/10.1038/nrc.2015.2.

39. Chaitanya GV, Steven AJ, Babu PP. PARP-1 cleavage fragments: signatures of cell-death proteases in neurodegeneration. Cell Commun Signal. 2010;8:31. https://doi.org/10.1186/1478-811X-8-31.

40. Oliver FJ, de la Rubia G, Rolli V, Ruiz-Ruiz MC, de Murcia G, Murcia JM-d. Importance of Poly(ADP-ribose) Polymerase and its cleavage in apoptosis: lesson from an uncleavable mutant. J Biol Chem. 1998;273(50):33533-9. https://doi.org/10.1074/jbc. 273.50.33533.

41. Mayor PC, Eng KH, Singel KL, Abrams SI, Odunsi K, Moysich $\mathrm{KB}$, et al. Cancer in primary immunodeficiency diseases: cancer incidence in the United States Immune Deficiency Network Registry. J Allergy Clin Immunol. 2018;141(3):1028-35. https://doi. org/10.1016/j.jaci.2017.05.024.

42. Vorechovsky I, Scott D, Haeney MR, Webster DA. Chromosomal radiosensitivity in common variable immune deficiency. Mutat Res. 1993;290:255-64.

43. Offer SM, Pan-Hammarström Q, Hammarström L, Harris RS. Unique DNA repair gene variations and potential associations with the primary antibody deficiency syndromes IgAD and CVID. PLoS ONE. 2010;5(8):e12260. https://doi.org/10.1371/journal. pone. 0012260 .
44. Christiansen M, Offersen R, Jensen JMB, Petersen MS, Larsen CS, Mogensen TH. Identification of novel genetic variants in CVID patients with autoimmunity, autoinflammation, or , malignancy. Front Immunol. 2020;10:3022. https://doi.org/10.3389/ fimmu.2019.03022.

45. de Valles-Ibáñez G, Esteve-Solé A, Piquer M, González-Navarro EA, Hernandez-Rodriguez J, Laayouni $\mathrm{H}$, et al. Evaluating the genetics of common variable immunodeficiency: monogenetic model and beyond. Front Immunol. 2018;9:636. https://doi.org/ 10.3389/fimmu.2018.00636.

46. Maffucci P, Filion C, Boisson B, Itan Y, Shang L, Casanova J, et al. Genetic diagnosis using whole exome sequencing in common variable immunodeficiency. Front Immunol. 2016;7:220. https://doi.org/10.3389/fimmu.2016.00220.

47. Weaver DA, Crawford EL, Warner KA, Elkhairi F, Khuder SA, Willey JC. ABCC5, ERCC2, XPA and XRCC1 transcript abundance levels correlate with cisplatin chemoresistance in non-small cell lung cancer cell lines. Mol Cancer. 2005;4(1):18. https://doi. org/10.1186/1476-4598-4-18.

48. Huang M-Y, Tsai H-L, Lin C-H, Huang C-W, Ma C-J, Huang $\mathrm{C}-\mathrm{M}$, et al. Predictive value of ERCC1, ERCC2, and XRCC1 overexpression for stage III colorectal cancer patients receiving FOLFOX-4 adjuvant chemotherapy. J Surg Oncol. 2013;108(7):45764. https://doi.org/10.1002/jso.23422.

49. Grieves JL, Fye JM, Harvey S, Grayson JM, Hollis T, Perrino FW. Exonuclease TREX1 degrades double-stranded DNA to prevent spontaneous lupus-like inflammatory disease. Proc Natl Acad Sci. 2015;112(16):5117-22. https://doi.org/10.1073/pnas.1423804112.

50. Hou G-X, Liu P, Yang J, Wen S. Mining expression and prognosis of topoisomerase isoforms in non-small-cell lung cancer by using Oncomine and Kaplan-Meier plotter. PLoS ONE. 2017;12(3):e0174515. https://doi.org/10.1371/journal.pone.01745 15.

51. Ballegaard V, Permin H, Katzenstein T, Marquart H, Schejbel L. Long-term follow-up on affinity maturation and memory B-cell generation in patients with common variable immunodeficiency. J Clin Immunol. 2013;33(6):1067-77. https://doi.org/10.1007/ s10875-013-9893-2.

52. Ferry BL, Jones J, Bateman EA, Woodham N, Warnatz K, Schlesier M, et al. Measurement of peripheral B cell subpopulations in common variable immunodeficiency (CVID) using a whole blood method. Clin Exp Immunol. 2005;140(3):532-9. https://doi.org/ 10.1111/j.1365-2249.2005.02793.x.

53. Wehr C, Kivioja T, Schmitt C, Ferry B, Witte T, Eren E, et al. The EUROclass trial: defining subgroups in common variable immunodeficiency. Blood. 2008;111(1):77-85.

54. Warnatz K, Denz A, Dräger R, Braun M, Groth C, Wolff-Vorbeck G, et al. Severe deficiency of switched memory B cells (CD27+IgM-IgD-) in subgroups of patients with common variable immunodeficiency: a new approach to classify a heterogeneous disease. Blood. 2002;99(5):1544-51. https://doi.org/10.1182/ blood.V99.5.1544.

55. Piqueras B, Lavenu-Bombled C, Galicier L, Cruyssen FB-VD, Mouthon L, Chevret S, et al. Common variable immunodeficiency patient classification based on impaired B cell memory differentiation correlates with clinical aspects. J ClinImmunol. 2003;23(5):385-400. https://doi.org/10.1023/A:1025373601374.

56. Rodríguez-Cortez VC, del Pino-Molina L, Rodríguez-Ubreva J, Ciudad L, Gómez-Cabrero D, Company C, et al. Monozygotic twins discordant for common variable immunodeficiency reveal impaired DNA demethylation during naïve-to-memory B-cell transition. Nat Commun. 2015;6(1):7335. https://doi.org/10.1038/ ncomms8335.

57. Recio MJ, Dominguez-Pinilla N, Perrig MS, Rodriguez VigilIturrate C, Salmón-Rodriguez N, Martinez Faci C, et al. Extreme phenotypes with identical mutations: two patients with same 
non-sense NHEJ1 homozygous mutation. Front Immunol. 2019;9:2959. https://doi.org/10.3389/fimmu.2018.02959.

58. Bateman EA, Ayers L, Sadler R, Lucas M, Roberts C, Woods A, et al. T cell phenotypes in patients with common variable immunodeficiency disorders: associations with clinical phenotypes in comparison with other groups with recurrent infections. Clin Exp Immunol. 2012;170(2):202-11. https://doi.org/10.1111/j.13652249.2012.04643.x.

59. Kidane D, Chae WJ, Czochor J, Eckert KA, Glazer PM, Bothwell $\mathrm{AL}$, et al. Interplay between DNA repair and inflammation, and the link to cancer. Crit Rev Biochem Mol Biol. 2014;49(2):11639. https://doi.org/10.3109/10409238.2013.875514.

60. Shao L. DNA damage response signals transduce stress from rheumatoid arthritis risk factors into T cell dysfunction. Front Immunol. 2018;9:3055. https://doi.org/10.3389/fimmu.2018.03055.

61. Li Y, Goronzy JJ, Weyand CM. DNA damage, metabolism and aging in pro-inflammatory $\mathrm{T}$ cells: Rheumatoid arthritis as a model system. Exp Gerontol. 2018;105:118-27. https://doi.org/ 10.1016/j.exger.2017.10.027.

62. Li Y, Shen Y, Hohensinner P, Ju J, Wen Z, Goodman SB, et al. Deficient activity of the nuclease MRE11A induces T cell aging and promotes arthritogenic effector functions in patients with rheumatoid arthritis. Immunity. 2016;45(4):903-16. https://doi. org/10.1016/j.immuni.2016.09.013.

63. Shao L, Fujii H, Colmegna I, Oishi H, Goronzy JJ, Weyand CM. Deficiency of the DNA repair enzyme ATM in rheumatoid arthritis. J Exp Med. 2009;206(6):1435-49. https://doi.org/10.1084/ jem.20082251.

64. Mensah KA, Chen JW, Schickel J-N, Isnardi I, Yamakawa N, Vega-Loza A, et al. Impaired ATM activation in B cells is associated with bone resorption in rheumatoid arthritis. Sci Transl Med. 2019;11(519):eaaw4626. https://doi.org/10.1126/scitranslm ed.aaw4626.

65. Kawanishi S, Ohnishi S, Ma N, Hiraku Y, Murata M. Crosstalk between DNA damage and inflammation in the multiple steps of carcinogenesis. Int J Mol Sci. 2017;18(8):1808. https://doi.org/ 10.3390/ijms 18081808 .
66. Murata M, Thanan R, Ma N, Kawanishi S. Role of nitrative and oxidative DNA damage in inflammation-related carcinogenesis. J Biomed Biotechnol. 2012;2012:623019. https://doi.org/10.1155/ 2012/623019.

67. Ioannidou A, Goulielmaki E, Garinis GA. DNA damage: from chronic inflammation to age-related deterioration. Front Genet. 2016;7:187. https://doi.org/10.3389/fgene.2016.00187.

68. Lopez-Gomez A, Clemente A, Cunill V, Pons J, Ferrer JM. IL-21 and anti-CD40 restore Bcl-2 family protein imbalance in vitro in low-survival CD27(+) B cells from CVID patients. Cell Death Dis. 2018;9(12):1156. https://doi.org/10.1038/ s41419-018-1191-8.

69. Ganjalikhani-Hakemi M, Yazdani R, Esmaeili M, Abolhassani $\mathrm{H}$, Rae W, Azizi G, et al. Role of apoptosis in the pathogenesis of common variable immunodeficiency (CVID). Endocr Metab Immune Disord Drug Targets. 2017;17(4):332-40. https://doi.org/ 10.2174/1871530317666170919120245.

70. Di Renzo M, Zhou Z, George I, Li Y, CunninghamRundles C. T cells from patients with common variable immunodeficiency undergo enhanced apoptosis and CD28 costimulation does not promote cell survival. Faseb J. 1998;12(5):A929-A.

71. Di Renzo M, Zhou Z, George I, Becker K, Cunningham-Rundles C. Enhanced apoptosis of T cells in common variable immunodeficiency (CVID): role of defective CD28 co-stimulation. Clin Exp Immunol. 2000;120(3):503-11. https://doi.org/10.1046/j. 1365-2249.2000.01239.x.

72. Saxon A, Keld B, Diaz-Sanchez D, Guo B-C, Sidell N. B cells from a distinct subset of patients with common variable immunodeficiency (CVID) have increased CD95 (Apo-1/fas), diminished CD38 expression, and undergo enhanced apoptosis. Clin Exp Immunol. 1995;102(1):17-25. https://doi.org/10.1111/j.13652249.1995.tb06630.x.

Publisher's Note Springer Nature remains neutral with regard to jurisdictional claims in published maps and institutional affiliations. 